\title{
Deoxyribonucleic Acid Relationships Among Hydrogen- Oxidizing Strains of the Genera Pseudomonas, Alcaligenes, and Paracoccus
}

\author{
G. AULING,${ }^{1} \dagger$ M. DITTBRENNER, ${ }^{2}$ M. MAARZAHL, ${ }^{2}$ T. NOKHAL, ${ }^{2}$ AND M. REH ${ }^{2}$ \\ Institut für Mikrobiologie der Universität Göttingen ${ }^{2}$ and Institut für Mikrobiologie der Gesellschaft für \\ Strahlen- und Umweltforschung $m b H,{ }^{1}$ München, in Göttingen, Federal Republic of Germany
}

Optical determination of deoxyribonucleic acid (DNA)-DNA reassociation kinetics was applied to the classification of 32 selected strains of hydrogen-oxidizing bacteria belonging to the genera Pseudomonas, Alcaligenes, and Paracoccus. The renaturation studies revealed a high intraspecies DNA homology for some strains of the species Pseudomonas palleronii, Pseudomonas pseudoflava, and Alcaligenes paradoxus, supporting former taxonomic concepts of different authors. The 12 denitrifying strains belonging to the genus Paracoccus were shown to be interrelated at various levels of percent degree of binding, and at least two clusters of very high genome-DNA relatedness have been found. DNA-DNA reassociation kinetics were also used for the calculation of the average molecular weight of genome DNA. The genome molecular weight of the hydrogen-oxidizing bacteria investigated in this study ranged from $3 \times 10^{9}$ to $5 \times 10^{9}$.

Defined as a physiological group, the "hydrogen bacteria" are aerobic chemolithotrophs that can use the oxidation of molecular hydrogen as an energy source. To accommodate these organisms, the genus Hydrogenomonas was proposed by Orla-Jensen in 1909. Davis et al. (5) rejected the genus Hydrogenomonas and proposed the assignment of all gram-negative strains of hydrogen-oxidizing bacteria to Pseudomonas, Alcaligenes, or Paracoccus. By this and later investigations of gram-negative, polarly flagellated, hydrogen-oxidizing bacteria and related strains $(1,2,5,6)$, the following nine hydrogen-oxidizing species of the genera Pseudomonas, Alcaligenes, and Paracoccus were established: Pseudomonas facilis, $P$. flava, $P$. pseudoflava, $P$. palleronii, $P$. saccharophila, Alcaligenes eutrophus, A. paradoxus, A. ruhlandii, and Paracoccus denitrificans. Serological methods have been used to show relatedness between strains of these species $(2,8)$. In spite of the intensive application of nucleic acid hybridization techniques for the classification of the pseudomonads $(14,16,17)$, only very few deoxyribonucleic acid (DNA)-DNA reassociations have been reported for hydrogen-oxidizing strains of the genera Pseudomonas and Alcaligenes $(2,18)$.

The present investigation was undertaken to confirm, by DNA-DNA reassociation studies, the establishment of new genera and species for

† Present address: Lehrgebiet für Mikrobiologie der Universität Hannover, Schneiderberg 50, D-3000 Hannover 1, Federal Republic of Germany. the gram-negative, hydrogen-oxidizing bacteria. Nine new denitrifying strains, isolated by $T$. Nokhal from our institute, were included in this study. Their characterization and comparison with known strains of Paracoccus denitrificans will be described in a separate paper (Nokhal and Schlegel, manuscript in preparation).

\section{MATERIALS AND METHODS}

Bacterial strains and culture conditions. The bacterial strains used in this study are listed in Table 1. In addition, Xanthomonas pelargonii ICPB P121 was used as a reference in molecular weight determinations and was grown in nutrient broth (Difco). The culture conditions and the media for growth and maintenance of the hydrogen-oxidizing strains have been described elsewhere (2). The purity of each strain was checked by microscopic observation and by plating on nutrient broth agar.

Preparation of DNA. Only cells from cultures grown to the stationary phase of the growth curve were harvested for isolation of DNA. The DNA was prepared by a light modification of the procedure of Marmur (12), which included repeated digestion of proteins by proteinase $\mathrm{K}$ (Merck) and digestion of ribonucleic acid by ribonuclease $A$ and $T 1$ (both Boehringer). The DNA solutions were considered as sufficiently purified if the extinction ratios $E_{2: 30} / E_{2600}: E_{260} /$ $E_{260}: E_{280} / E_{260}$ were about 0.450:1.00:0.515. Crude DNA from four of the newly isolated denitrifying hydrogenoxidizing Paracoccus strains was kindly provided by $T$. Nokhal from this institute.

DNA-DNA renaturation. Five-milliliter quantities of DNA in 1 $\times$ SSC (standard saline citrate) buffer were dialyzed at room temperature against $0.667 \mathrm{M}$ sodium-phosphate buffer, pH 7.0. After 3 days of dialysis with several buffer changes, the DNA solutions 
TABLE 1. List of strains studied"

\begin{tabular}{|c|c|c|c|c|c|}
\hline \multirow{2}{*}{ Species } & \multicolumn{3}{|c|}{ Strain no. } & \multirow{2}{*}{ Received from: } & \multirow{2}{*}{ Reference/remark } \\
\hline & Authors' & DSM & ATCC & & \\
\hline Alcaligenes & & 531 & 17697 & ICC & (5) \\
\hline A. eutrophus & H16 & 428 & 17699 & ICC & (5) \\
\hline A. faecalis & & 30030 & 8750 & DSM & $\begin{array}{l}\text { Type species of the genus Alcali- } \\
\text { genes; emended description by } \\
\text { Hendrie et al. (10) }\end{array}$ \\
\hline A. paradoxus & 351 & 30034 & 17713 & ICC & (5) \\
\hline A.paradoxus & 353 & 646 & 17715 & DSM & (5) \\
\hline A. paradoxus & $12 \mathrm{x}$ & & & $\mathrm{ICC}$ & $\begin{array}{l}\text { Identified by Wilde as } A \text {. para- } \\
\text { doxus }\end{array}$ \\
\hline Paracoccus denitrificans & $\mathrm{S}$ & 65 & 17741 & ICC & $(5)$ \\
\hline P. denitrificans & V & 415 & & ICC & (20) \\
\hline P. denitrificans & $\mathbf{M}$ & 413 & & Nokhal & (4) \\
\hline Paracoccus sp. & N1 & & & Nokhal) & \\
\hline Paracoccus sp. & N2 & & & Nokhal & \\
\hline Paracoccus sp. & N3 & & & Nokhal & \\
\hline Paracoccus sp. & N4 & & & Nokhal & Isolated and identified by Nokhal \\
\hline Paracoccus sp. & N5 & & & Nokhal & as $P$. denitrificans or regarded \\
\hline Paracoccus sp. & N6 & & & Nokhal & as similar to $P$. denitrificans \\
\hline Paracoccus sp. & N7 & & & Nokhal & \\
\hline Paracoccus sp. & N9 & & & Nokhal & \\
\hline Paracoccus sp. & N10 & & & Nokhal & \\
\hline Pseudomonas facilis & 332 & & 17695 & ICC & (5) \\
\hline P. flava & & 619 & & DSM & (11) \\
\hline P. pseudoflava & GA3 & 1034 & & & (2) \\
\hline P. pseudoflava & $9 \mathrm{~B} 32$ & & & Lalucat & $\begin{array}{l}\text { Identified by Lalucat as } P \text {. pseu- } \\
\quad \text { doflava }\end{array}$ \\
\hline Pseudomonas sp. & 9B31 & & & Lalucat & Related to P. pseudoflava \\
\hline Pseudomonas sp. & GA6 & & & & \\
\hline Pseudomonas sp. & MA30 & & & Aragno & May be related to $P$. pseudoflava \\
\hline P. palleronii & 362 & 63 & 17724 & ICC & (6) \\
\hline P. palleronii & 366 & 650 & 17728 & DSM & (6) \\
\hline P. palleronii & RH2 & & & Reh & Identified by Reh as $P$. palleronii \\
\hline P. palleronii & Z32 & & & Savel'eva & Identified as Hydrogenomonas \\
\hline Pseudomonas sp. & $\mathrm{Z} 17$ & & & Sevel'eva & $\begin{array}{l}\text { pantotropha by Savel'eva and } \\
\text { Zhilina (19) }\end{array}$ \\
\hline P. saccharophila & & 654 & 15946 & DSM & (5) \\
\hline
\end{tabular}

"Abbreviations: ATCC, American Type Culture Collection, Rockville, Md.; DSM, Deutsche Sammlung von Mikroorganismen, Göttingen, Federal Republic of Germany; ICC, Institute's (Göttingen) Culture Collection.

were sheared by repeated $(2 \times)$ passage through a French pressure cell at about $1.5 \times 10^{6} \mathrm{~Pa}$. The fragmented samples were centrifuged for $30 \mathrm{~min}$ at 4,000 rpm and adjusted to $E_{260}$ of 1.25 .

A combination of the methods of De Ley et al. (7) and of Gillis et al. (9) as well as of the procedure of Bradley (3) was developed for optical determination of the reassociation kinetics of DNA in sodium phosphate buffer. Formamide was added to the adjusted DNA samples, giving a final solvent concentration of $25 \%$ (vol/vol) formamide and $0.5 \mathrm{M}$ sodium phosphate, $\mathrm{pH}$ 7.0. Three DNA solutions (DNA of A; DNA of B; a mixture of equal volumes of DNA of $A$ and of DNA of $B$ ) and a blank with adenine were heat denatured in a recording spectrophotometer with an attached temperature programmer (Gilford Instruments Laboratories, Inc.). The denaturing temperature $\left(95^{\circ} \mathrm{C}\right)$ was maintained for $15 \mathrm{~min}$, and then the temperature was rapidly adjusted to $25^{\circ} \mathrm{C}$ below the midpoint of thermal denaturation of the DNA $\left(T_{m}\right)$. Because the mid- points of the hyperchromic shifts in the employed phosphate-formamide buffer system were about $85^{\circ} \mathrm{C}$ for most of the strains examined, we decided to use $60^{\circ} \mathrm{C}$ as the optimal temperature for renaturation throughout the study. The mean guanine plus cytosine $(\mathrm{G}+\mathrm{C})$ content of all strains tested was about 60 to 70 $\mathrm{mol} \%$ (2, 6; unpublished data of T. Nokhal and of our laboratory). The absorbance at $270 \mathrm{~nm}$ was monitored for 30 min unless otherwise stated. This denaturationrenaturation procedure was repeated five or six times for each sample.

\section{RESULTS}

Calculations of the degree of binding and of genome size are based on comparison of renaturation rate constants, which are only reliable when reassociation, as monitored optically, proceeds as a second-order reaction $(9,22)$. Initial linearity of the recorded renaturation lines due 
to second-order kinetics was obtained in every case for some $\mathbf{4 0} \mathrm{min}$ after the onset of the reassociation conditions. The degree of binding between the denatured DNA samples was calculated by the method of De Ley et al. (7). Attempts to monitor the reassociation reactions for longer times to obtain $\mathrm{C}_{0} \mathrm{~T}_{1 / 2}$ values as described by Bradley (3) did not result in stringent second-order kinetics. Under our test conditions the plots always showed a slight deviation from the needed linearity. We nevertheless tried to calculate the degree of nucleotide sequence homology for some reassociations by the method of Bradley (3). The results thus found proved to be 10 to $20 \%$ lower than those obtained from the initial linear renaturation lines of De Ley et al. (7).

For our DNA-DNA renaturation studies, we selected P. palleronii 362, P. pseudoflava GA3, $P$. flava DSM $619, A$. paradoxus 351 , and $P$. denitrificans $S$ as references because they were type strains. In addition, $P$. denitrificans $M$ and Paracoccus sp. N4 were chosen because they seemed to be "centrally" located in a group of phenetically studied, denitrifying, hydrogen-oxidizing strains ( $T$. Nokhal, unpublished data). The resulting DNA homologies are presented in Tables 2 and 3.
In the $P$. palleronii homology group, $P$. pal . leronii 362 and $P$. palleronii 366 , the only strains used by Davis et al. (6) in their proposal of a new species, showed identical polynucleotide sequences. Strain Z32, identified as Pseudomonas pantotropha by Savel'eva and Zhilina (19) and strain $\mathrm{RH} 2$, previously identified as $P$. palleronii (Reh, unpublished data), also exhibited close relatedness to $P$. palleronii 362 .

Several strains of the P. pseudoflava homology group included in this study (strains GA2, GA3, and GA4) have already been subjected to an extensive characterization which resulted in the proposal of $P$. pseudoflava (2). Further strains, aside from 9B32, subsequently isolated by different authors showed only moderate or remote relatedness to $P$. pseudoflava GA3.

Of the strains tested for degree of binding to $P$. flava DSM 619 , only a few showed moderate relatedness. In the $A$. paradoxus homology group, strains 351 and 353 had nearly identical polynucleotide sequences, and strain $12 \mathrm{X}$ was closely related to the reference (type) strain $A$. paradoxus 351 . Absolutely no relatedness was found between $A$. paradoxus 351 and strain DSM 30030 of $A$. faecalis, the type species of the genus Alcaligenes.

The data from the optical reassociation of 12

TABLE 2. Degree of binding (\%D) among various strains of hydrogen-oxidizing bacteria

\begin{tabular}{|c|c|c|c|c|c|}
\hline \multirow[b]{2}{*}{ Species } & \multirow[b]{2}{*}{ Strain" } & \multicolumn{4}{|c|}{ \%D with } \\
\hline & & $\begin{array}{c}\text { P. palleronii } \\
362\end{array}$ & $\begin{array}{c}P . \text { pseudoflava } \\
\text { GA3 }\end{array}$ & $\begin{array}{l}\text { P. flava } D S M \\
619\end{array}$ & $\begin{array}{c}\text { A. paradoxus } \\
351\end{array}$ \\
\hline Pseudomonas palleronii & 362 & 100 & & & \\
\hline P. palleronii & 366 & 99 & & & \\
\hline P. palleronii & Z32 & 84 & & & \\
\hline P. palleronii & $\mathrm{RH} 2$ & 76 & & & \\
\hline Pseudomonas sp. & $\mathrm{Z} 17$ & 64 & & & \\
\hline Pseudomonas pseudoflava & GA3 & 25 & 100 & & \\
\hline P. pseudoflava & GA4 & & $99^{b}$ & 62 & \\
\hline P. pseudoflava & GA2 & & $85^{h}$ & 52 & \\
\hline P. pseudoflava & 9B32 & & 100 & & \\
\hline Pseudomonas sp. & 9B31 & & 69 & & \\
\hline Pseudomonas sp. & GA6 & & 62 & 43 & \\
\hline Pseudomonas sp. & MA30 & & 41 & & \\
\hline Pseudomonas flava & DSM 619 & 34 & 65 & 100 & \\
\hline$P$. facilis & 332 & 15 & 37 & 18 & \\
\hline P. saccharophila & DSM 654 & 16 & 12 & 18 & \\
\hline Alcaligenes paradoxus & 351 & 17 & 34 & 29 & 100 \\
\hline A. paradoxus & 353 & & 20 & & 96 \\
\hline A. paradoxus & $12 X$ & & & & 76 \\
\hline A. eutrophus & H16 & & 6 & 24 & 39 \\
\hline A. eutrophus & DSM 531 & & & & 18 \\
\hline A. faecalis & DSM 30030 & & & & 6 \\
\hline
\end{tabular}

\footnotetext{
${ }^{a}$ Abbreviations: DSM, Deutsche Sammlung von Mikroorganismen, Göttingen, Federal Republic of Germany.
}

${ }^{b}$ Data from Auling et al. (2). 
TABLE 3. Degree of binding (\%D) of hydrogen-oxidizing bacteria of the genus Paracoccus

\begin{tabular}{|c|c|c|c|c|}
\hline \multirow{2}{*}{ Species } & \multirow{2}{*}{ Strain } & \multicolumn{3}{|c|}{ \%D with } \\
\hline & & $\mathbf{S}$ & $\mathbf{M}$ & $\mathrm{N}_{4}$ \\
\hline P. denitrificans & $\mathbf{S}$ & 100 & $54 \pm 5$ & $68 \pm 10$ \\
\hline P. denitrificans & $\mathbf{M}$ & $54 \pm 5$ & 100 & $57 \pm 4$ \\
\hline$P$. denitrificans & V & $51 \pm 3$ & $106 \pm 4$ & $57 \pm 2$ \\
\hline Paracoccus sp. & N4 & $51 \pm 9$ & $53 \pm 3$ & 100 \\
\hline Paracoccus sp. & $\mathrm{Nl}$ & $52 \pm 5$ & $52 \pm 4$ & $98 \pm 5$ \\
\hline Paracoccus sp. & N2 & $60 \pm 6$ & $52 \pm 5$ & $98 \pm 7$ \\
\hline Paracoccus sp. & N3 & $48 \pm 1$ & $64 \pm 6$ & $87 \pm 2$ \\
\hline Paracoccus sp. & N5 & $47 \pm 3$ & $68 \pm 10$ & $81 \pm 3$ \\
\hline Paracoccus sp. & N6 & $53 \pm 2$ & $58 \pm 3$ & $81 \pm 4$ \\
\hline Paracoccus sp. & N7 & $54 \pm 2$ & $62 \pm 2$ & $82 \pm 2$ \\
\hline Paracoccus sp. & N9 & $40 \pm 4$ & $63 \pm 2$ & $50 \pm 2$ \\
\hline Paracoccus sp. & N10 & $53 \pm 2$ & $61 \pm 9$ & $57 \pm 5$ \\
\hline
\end{tabular}

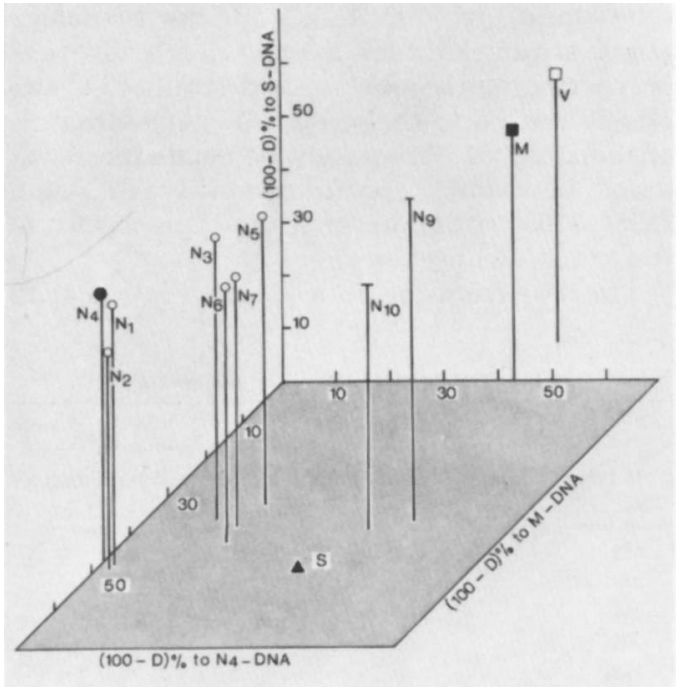

Fig. 1. Diagrammatic representation of the relat edness between 12 strains of the genus Paracoccus. The symbols mark the position of the strains in the diagram. Black symbols were chosen for the reference strains $(\boldsymbol{\Delta}, P$. denitrificans $S, \boldsymbol{Q}, \boldsymbol{P}$. denitrificans $\boldsymbol{M}$, - Paracoccus sp. N4). White symbols were chosen for strains with a very high degree of binding to any of the reference strains $(\square$, strains of the P. denitrificans M-homology group, $O$, strains of the Paracoccus sp. N4-homology group). The symbol $T$ marks the position of those strains which could not be assigned to any homology group.

denitrifying strains of the genus Paracoccus revealed more than one DNA homology group. All the Paracoccus strains examined were characterized by a degree of binding ranging from at least 40 up to $100 \%$ to the three reference strains- $P$. denitrificans $\mathrm{S}, P$. denitrificans $\mathrm{M}$, and Paracoccus sp. N4 (Table 3). The clustering of the Paracoccus strains on the basis of their percent degree of binding to the Paracoccus strains cited above has been illustrated graphically (Fig. 1) according to the suggestions of $R$. Lungershausen $(\mathrm{Ph}$. D. thesis, Universtät Göttingen, Göttingen, Federal Republic of Germany, 1978).

For genome size determinations, we compared the apparent renaturation rates of our DNA samples in relation to each other and in relation to $X$. pelargonii ICPB P121. Gillis et al. (9) described the haploid genome of $X$. pelargonii as having a mean $\mathrm{G}+\mathrm{C}$ content of $66.5 \mathrm{~mol} \%$ (similar to the value reported for most of the hydrogen-oxidizing strains examined) and a molecular weight of $2.4 \times 10^{9}$. Therefore, no corrections for differences in the $\mathrm{G}+\mathrm{C}$ content were necessary. The results of our genome size calculations, applying equation $M_{1} / M_{2}=K_{2}^{\prime} K_{1}^{\prime}$ of Gillis et al. (9), are summarized in Table 4 . The average molecular weight of the genome DNA from the strains of the genus Paracoccus was about $3 \times 10^{9}$ and ranged from $3 \times 10^{9}$ to $4 \times 10^{9}$ for the strains of the genus Pseudomonas. The strains of the genus Alcaligenes were found to have a genome with the largest molecular weight $\left(4 \times 10^{9}\right.$ to $\left.5 \times 10^{9}\right)$.

\section{DISCUSSION}

The demonstration of isolated DNA homology groups within the gram-negative, hydrogenoxidizing strains as revealed by the combined results of this and a recent study (2) gives further support to the taxonomic subdivision (5) of this group of physiologically related aerobic bacteria previously assigned to the genus Hydrogenomonas.

The first attempt to obtain DNA-DNA homology evidence for the abandonment of this genus was made by Ralston et al. (18), who used 
TABLE 4. Average molecular weight of genome DNA from some hydrogen-oxidizing species"

\begin{tabular}{|c|c|c|}
\hline DNA source & $\begin{array}{l}\text { No. of deter- } \\
\text { minations }\end{array}$ & $\begin{array}{c}\text { Mol wt (X } \\
\left.10^{-4}\right)(\mathrm{Na} \text {-salt }\end{array}$ \\
\hline Pseudomonas palleronii 362 & 12 & 2.8 \\
\hline P. palleronii 366 & 6 & 3.1 \\
\hline P. palleronii $\mathrm{Z32}$ & 6 & 2.5 \\
\hline P. pseudoflava GA3 & 24 & 3.7 \\
\hline P. pseudoflava 9B32 & 5 & 4.4 \\
\hline P. flava DSM 619 & 15 & 3.1 \\
\hline P. facilis 332 & 9 & 2.8 \\
\hline P. saccharophila DSM 654 & 9 & 3.5 \\
\hline Alcaligenes paradoxus 351 & 15 & 4.7 \\
\hline A. paradoxus 353 & 3 & 4.8 \\
\hline A. eutrophus $\mathrm{H} 16$ & 3 & 4.1 \\
\hline A. eutrophus DSM 531 & 3 & 5.1 \\
\hline Paracoccus denitrificans S & 36 & 2.5 \\
\hline P. denitrificans $\mathrm{M}$ & 36 & 3.0 \\
\hline P. denitrificans $\mathrm{V}$ & 18 & 2.7 \\
\hline Paracoccus sp. N4 & 36 & 3.4 \\
\hline Paracoccus sp. N1 & 9 & 2.9 \\
\hline Paracoccus sp. N2 & 9 & 3.3 \\
\hline Paracoccus sp. N3 & 18 & 2.9 \\
\hline Paracoccus sp. N5 & 18 & 2.9 \\
\hline Paracoccus sp. N6 & 18 & 3.0 \\
\hline Paracoccus sp. N7 & 18 & 3.0 \\
\hline Paracoccus sp. N9 & 18 & 2.6 \\
\hline Paracoccus sp. N10 & 9 & 2.9 \\
\hline
\end{tabular}

"Abbreviations: DSM, Deutsche Sammlung von Mikroorganismen, Göttingen Federal Republic of Germany.

the competition and direct-binding methods of Palleroni and Doudoroff (15). They found close relatedness of the hydrogen-oxidizing species. $P$. facilis and the nonautotrophic species Pseudomonas delafieldii as well as no relatedness between the species Alcaligenes eutrophus and other autotrophic and nonautotrophic pseudomonads studied. The taxonomic concept of Davis et al. $(5,6)$ establishing $A$. paradoxus and $P$. palleronii (with only two strains under investigation) as separate species has been confirmed by our DNA-DNA reassociation data (see Table 2 ). None of the hydrogen-oxidizing strains tested in our renaturation studies was found to be identical or closely related to $P$. flava DSM 619 . There does exist moderate DNA homology between $P$. flava and the still expanding species $P$. pseudoflava (see Table 2 of this study and Auling et al., 1978).

Davis et al. $(5,6)$ have proposed the species Paracoccus denitrificans for gram-negative, coccoid, denitrifying, hydrogen-oxidizing bacteria on the basis of the two or three strains examined. Differences between $P$. denitrificans $\mathrm{S}$ and $P$. denitrificans $\mathrm{M}$ with respect to cell wall composition and nutritional spectrum have been reported by Walther-Mauruschat et al. (21). Our DNA renaturation studies with 12 autotrophic strains of the genus Paracoccus, including nine denitrifying bacteria newly isolated by T. Nokhal from our institute, revealed differences between the hitherto described strains as well as between the new strains, tentatively identified as $P$. denitrificans by T. Nokhal. The data presented in Table 3 and Fig. 1 show that the denitrifying, hydrogen-oxidizing strains are interrelated at various levels of DNA homology. None of the Paracoccus strains tested exhibited a close relationship to strain $\mathrm{S}$ of $P$. denitrificans, the type species of the genus. At least two clusters of very high genome-DNA relatedness were found; these were grouped around either $P$. denitrificans $\mathbf{M}$ or Paracoccus sp. N4.

Phenotypic characterization of the newly found denitrifying strains and their comparison with the previously described strains of $P$. denitrificans is currently under investigation. The taxonomic and nomenclatural implications of the results of this investigation on the genus Paracoccus will be reported more fully in the near future (Nokhal and Schlegel, manuscript in preparation).

\section{ACKNOWLEDGMENTS}

We thank H. G. Schlegel, in whose institute this study was undertaken, for his interest and support. Cultures of bacterial strains were received from M. Aragno, J. De Ley, J. Lalucat, T. Nokhal, and N. D. Savel'eva. We are indebted to T. Nokhal for providing us with DNA from four of his newly isolated Paracoccus strains.

\section{REPRINT REQUESTS}

Address reprint requests to: Dr. M. Reh, Institut für Mikrobiologie, Abteilung für Bakterienphysiologie der Universität Göttingen, Grisebachstr. 8, D-3400 Göttingen, Federal Republic of Germany.

\section{LITERATURE CITED}

1. Aragno, M., and H. G. Schlegel. 1977. Alcaligenes ruhlandii (Packer and Vishniac) comb. nov., a peritrichous hydrogen bacterium previously assigned to Pseudomonas. Int. J. Syst. Bacteriol. 27:279-281.

2. Auling, G., M. Reh, C. M. Lee, and H. G. Schlegel. 1978. Pseudomonas pseudoflava, a new species of hydrogen-oxidizing bacteria: its differentiation from Pseudomonas flava and other yellow-pigmented, gram-negative hydrogen-oxidizing species. Int. J. Syst. Bacteriol. 28:82-95.

3. Bradley, S. G. 1973. Relationships among mycobacteria and nocardiae based upon deoxyriboncleic acid reassociation. J. Bacteriol. 113:645-651.

4. Chang, J. P., and J. G. Morris. 1961. Studies on the utilization of nitrate by Micrococcus denitrificans. J. Gen. Microbiol. 29:301-310.

5. Davis, D. H., M. Doudoroff, R. Y. Stanier, and M. Mandel. 1969. Proposal to reject the genus Hydrogenomonas: taxonomic implications. Int. J. Syst. Bacteriol. 19:375-390.

6. Davis. D. H., R. Y. Stanier, M. Doudoroff, and $M$. Mandel. 1970. Taxonomic studies on some gram-nega- 
tive polarly flagellated "hydrogen-bacteria" and related species. Arch. Microbiol. 70:1-13.

7. De Ley, J., H. Cattoir, and A. Reynaerts. 1970. The quantitative measurement of DNA-hybridizations from renaturation rates. Eur. J. Biochem. 12:133-142.

8. Detrick-Hooks, B., and E. R. Kennedy. 1974. Immunological cross-reactions among strains of Hydrogenomonas, Pseudomonas and Alcaligenes. Antonie van Leeuwenhoek J. Microbiol. Serol. 40:577-584.

9. Gillis, M., J. De Ley, and M. De Cleene. 1970. The determination of molecular weight of bacterial genome DNA from renaturation rates. Eur. J. Biochem. 12:143153.

10. Hendrie, M. S., A. J. Holding, and J. M. Shewan. 1974. Emended descriptions of the genus Alcaligenes and of Alcaligenes faecalis and proposal that the generic name Achromobacter be rejected: status of the named species of Alcaligenes and Achromobacter. Int. J. Syst. Bacteriol. 24:534-550.

11. Kluyver, A. J., and A. Manten. 1942. Some observations on the metabolism of bacteria oxidizing molecular hydrogen. Antonie van Leeuwenhoek, J. Microbiol. Serol. 8:71-85.

12. Mamur, J. 1961. A procedure for the isolation of deoxyribonucleic acid from microorganisms. J. Mol. Biol. 3: 208-218.

13. Orla-Jensen, S. 1909. Die Hauptlinien des natürlichen Bakteriensystems. Zentralbl. Bakteriol. Parasitenkd. Infektionskr. Hyg. Abt. 2 22:305-346.

14. Palleroni, N. J., R. W. Ballard, E. Ralston, and M.
Doudoroff. 1972. Deoxyribonucleic acid homologies among some Pseudomonas species. J. Bacteriol. 110:111.

15. Palleroni, N. J., and M. Doudoroff. 1971. Phenotypic characterization and deoxyribonucleic acid homologies of Pseudomonas solanacearum. J. Bacteriol. 107:690696.

16. Palleroni, N. J., R. Kunisawa, R. Contopoulou, and M. Doudoroff. 1973. Nucleic acid homologies in the genus Pseudomonas. Int. J. Syst. Bacteriol. 23:333-339.

17. Pecknold, P. C., and R. G. Grogan. 1973. Deoxyribonucleic acid homology groups among phytopathogenic Pseudomonas species. Int. J. Syst. Bacteriol. 23:111121.

18. Ralston, E., N. J. Palleroni, and M. Doudoroff. 1972. Deoxyribonucleic acid homologies of some so-called "Hydrogenomonas" species. J. Bacteriol. 109:465-466.

19. Savel eva, N. D., and T. N. Zhilina. 1968. Taxonomy of hydrogen bacteria. Microbiology (USSR) 37:68-73. (Translated from Microbiologya)

20. Vogt, M. 1965. Wachstumsphysiologische Untersuchungen an Micrococcus denitrificans Beijerinck. Arch. Microbiol. 50:256-281.

21. Walther-Mauruschat, A., M. Aragno, F. Mayer, and H. G. Schlegel. 1977. Micromorphology of gram-negative hydrogen bacteria. II. Cell envelope, membranes and cytoplasmic inclusions. Arch. Microbiol. 114:101110.

22. Wetmur, J. G., and N. Davidson. 1968. Kinetics of renaturation of DNA. J. Mol. Biol. 31:349-370. 